\title{
GASTRIC CANCER PATIENTS TREATED BY A GENERAL OR GASTRIC CANCER SURGICAL TEAM: a comparative study
}

\author{
Fernando 0. SOUZA' ${ }^{1}$, Dalnei V. PEREIRA² ${ }^{2}$ Luís H. SANTOS ${ }^{2}$, Luis ANTUNES ${ }^{2}$ and Juarez CHIESA ${ }^{2}$
}

\begin{abstract}
Background - Although gastric cancer has been decreasing in incidence in many countries, it is still the second most common cause of cancer deaths worldwide. Its prognosis is poor and depends, among other factors, on early diagnosis as well as on surgeon expertise. Aim - To compare the outcomes of gastric cancer patients treated at a university hospital by a general surgical team and later on by a gastric cancer surgical team. Methods - Gastric cancer patients were separated into two groups according to whether they were treated by a general surgical team (group 1, $\mathrm{n}=136 ; 1984$ to 1993) or by gastric cancer team (group 2, $\mathrm{n}=149 ; 1994$ to 2003). Clinical and pathologic features and survival rates were assessed. Results - During a 20-year period, a decreased number of patients underwent surgical resection in the second period ( $94 \%$ vs $86 \%)$, a greater number of upper gastrointestinal endoscopies were performed resulting in an increased number of tumors diagnosed as stage I ( $5 \%$ vs $22 \%$ ). Also, D2 gastrectomies were more frequently performed instead of D0 gastrectomies and negative surgical margins were adequate. Mortality decreased from $9 \%$ to $6 \%$ in group 1 and 2 , respectively and adjuvant therapy has been considered. Conclusion - Surgical specialized units for gastric cancer are necessary if better results are to be expected since this approach definitely provides better patient care.
\end{abstract}

HEADINGS - Stomach neoplasms, surgery. Gastrectomy.

\section{INTRODUCTION}

Although the incidence of gastric cancer is decreasing in many countries, mainly in developed ones, it continues to be one of the most frequent tumors, when considering both genders, and it is ranked in the fourth position, following lung, breast and colon cancers, representing the second greatest cause of cancer deaths, worldwide. Every year, there are 935,000 new cases, of which 23,000 are diagnosed in $\operatorname{Brazil}^{(7,49,54)}$.

In southern Brazil, in the state of Rio Grande do Sul the incidence of gastric cancer is the greatest in the country (23/100,000 male inhabitants) and 1,770 new cases are estimated for 2006, according to the National Cancer Institute $-\mathrm{INCA}^{(7)}$.

The number of patients with gastric cancer surviving 5 years after diagnosis and who were mainly submitted to surgical treatment has increased over the past few years in western countries ${ }^{(2)}$, especially in specialized gastrointestinal units ${ }^{(17)}$, though this figure remains far below those results obtained by Japanese authors ${ }^{(31)}$. This is due to the fact that cure or increased survival depends, as in many cancers, on early diagnosis ${ }^{(8)}$. Toward this purpose, a large amount of financial resources is needed to identify individuals at risk and to select patients who may be generally in an asymptomatic phase leading to, in most cases, diagnosis at an earlier stage and as a consequence contributing to improve overall outcomes, such as operability, resection and survival rates.

The cost/benefit relationship for screening patients with gastric cancer is considerably unfavorable when other Brazilian public health priorities are considered. Therefore, we have been keeping a rate of about $15 \%$ of early-diagnosed cases in the country ${ }^{(20,26)}$, which is quite lower as compared to Japan, for instance, where a rate of $50 \%$ or over can be achieved due to a great effort established long ago to search for gastric cancer ${ }^{(31)}$.

However, improvement of those rates is not only achieved by large investments on screening but the establishment of specialized services, such as The Stomach and Small Intestine Surgical Service - SSISS or "Stomach Cancer Groups", allows the referring of cases and, therefore improves quality of surgeons, due to continued practice, increase on experience, knowledge and motivation, all that results in improvement on quality of the services ${ }^{(1)}$.

This paper addresses the results of a 20 -year period in the treatment of gastric cancer in a university hospital

'Surgical Unit of the Stomach and Small Intestine; '2Department of Onco-Hematology and Radiotherapy, University Hospital, Federal University of Santa Maria, RS, Brazil.

Correspondence: Dr. Fernando O. Souza - Universidade Federal de Santa Maria - Faculdade de Medicina - Hospital Universitário - Faixa de Camobi, km 9 - $97105-900$ - Santa Maria, RS, Brazil. E-mail: fsouza@via-rs.net 
comparing those patients treated in the first half by several general surgeons and in the second half, by a gastric cancer surgeon exclusively.

\section{METHODS}

The University Hospital of the Federal University of Santa Maria, RS, Brazil is a regional referring hospital for the 43 cities in central region of the Rio Grande do Sul state, covering a population of 1.5 million inhabitants. Upon its opening in 1984, a General Surgery Service was established, which was responsible for all surgical problems, including gastric cancer. Later, surgical specialty units were established, including Urology, Cardiovascular surgery, Thoracic surgery, Coloproctology, and finally in 1994 Gastrointestinal surgery was divided into Esophageal, Stomach and Small Intestine, Liver, Billiary tract and Pancreas, Hernias and Abdominal Wall units.

When management of the SSISS was taken over, data was collected from the record of all patients with gastric cancer treated by general surgeons (1984 to 1993, first half) and was assembled into a database developed for this purpose and that should be used to store data from gastric cancer patients treated by a gastric cancer surgeon, thereafter. Ten years later (second half, 1994 to 2003), a comparative analysis of the two halves was performed to evaluate the outcome on the quality of treatment obtained before and after the establishment of this specialized unit for gastric cancer.

In the first half there were 136 patients (101 male, 35 female; mean age $=64$ years $)$ and in the second half there were 149 patients ( 96 male, 53 female; mean age $=60$ years) and the clinicopathologic characteristics are shown in Table 1.

TABLE 1. Clinicopathologic characteristics

\begin{tabular}{lccc}
\hline Characteristics & $\begin{array}{c}\text { 1st period } \\
(\mathrm{n}=136)\end{array}$ & $\begin{array}{c}\text { 2nd period } \\
\mathrm{n}=149)\end{array}$ & $\boldsymbol{P}^{*}$ \\
\hline Sex & $101(74 \%)$ & $96(64 \%)$ & $\mathrm{ns}$ \\
$\quad$ Male & $34(26 \%)$ & $53(36 \%)$ & \\
$\quad$ Female & 63.9 & 59.7 & 0.042 \\
Age (mean) & $128(94 \%)$ & $129(86 \%)$ & $\mathrm{ns}$ \\
Operability & $9(9 \%)$ & $7(6 \%)$ & 0,0001 \\
Mortality (resection) & & & \\
Lymphadenectomy & $87(85 \%)$ & $0(0 \%)$ & 0,0001 \\
D0 & $16(15 \%)$ & $19(10 \%)$ & \\
D1 & $0(0 \%)$ & $92(90 \%)$ & \\
D2 & & & \\
PTNM stage & $5(5 \%)$ & $22(22 \%)$ & \\
I & $8(8 \%)$ & $14(14 \%)$ & \\
II & $27(26 \%)$ & $35(34 \%)$ & \\
III & $63(61 \%)$ & $31(30 \%)$ & \\
IV & &
\end{tabular}

The two periods were compared for patient awareness of the disease, number of upper gastrointestinal endoscopies performed, surgical resection rate, surgical techniques, tumor stages, surgical mortality, adjuvant treatments and follow-up.
Statistical analysis was performed using the chi-square test, with $P<0.05$ considered as significant and a confidence interval of $95 \%$. Survival curve was calculated by Kaplan-Meyer method ${ }^{(30)}$.

\section{RESULTS}

In the first period, restricted information about gastric cancer was given to the patient or to family members, sometimes even omitting the real conditions of the patients. On the contrary, in the second half, after the establishment of the SSISS, in addition to full information given to the patients and family members who also took part on surgical decisions, there was thorough information given to the community through brochures, newspaper issues as well as television and radio programs. This approach led to not only an increased number of appointments to the SSISS but also to an increase in the number of upper gastrointestinal endoscopies (Figure 1).

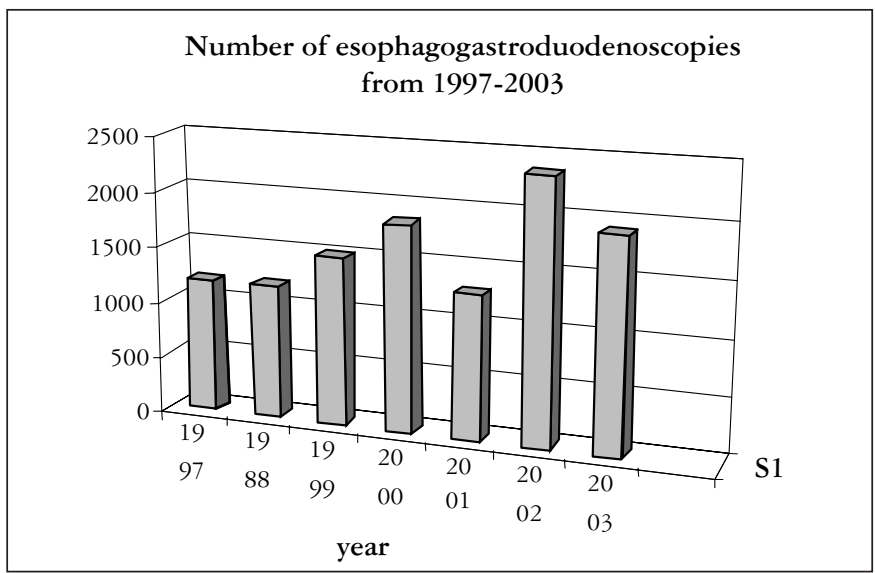

FIGURE 1. Number of high digestive endoscopies carried out at the University Hospital of Santa Maria between 1997 and 2003

During the second period, 149 patients were identified. Twenty $(13 \%)$ of them presented with far advanced disease and even palliative surgical procedures were not indicated. The remaining 129 patients had undergone gastric resections $(\mathrm{n}=102 ; 79 \%)$ diagnostic laparotomies or bypass procedures $(\mathrm{n}=27 ; 21 \%)$. Of the 102 resections, $64(63 \%)$ were potentially curative (R0) and $38(37 \%)$ were palliative procedures (R2). There were seven $(6,8 \%)$ and four $(14 \%)$ postoperative hospital deaths in the resection and non-resection gastric tumors, respectively. Seventeen (13\%) patients were lost to follow-up and 91 were included in the survival curve calculations. The 5 -year survival rates were $81 \%, 43 \%$, $18 \%$, and $0 \%$ for stage I through IV, respectively (Figure 2).

As for operability, it was greater in the first period, where it was understood that all gastric cancer patients "deserved" a surgical attempt. However, in the second period, it was lower because a more precise staging assessment, including an accurate clinical and image examination was routinely performed. Recently, laparoscopy was added to determine patients that would not benefit from surgical approach, such as those with metastatic disease and absence of bleeding or obstruction. 
Overall survival curves of operated patients for gastric cancer according to the stage, excluding postoperative hospital deaths - Complete $\because$ Censored

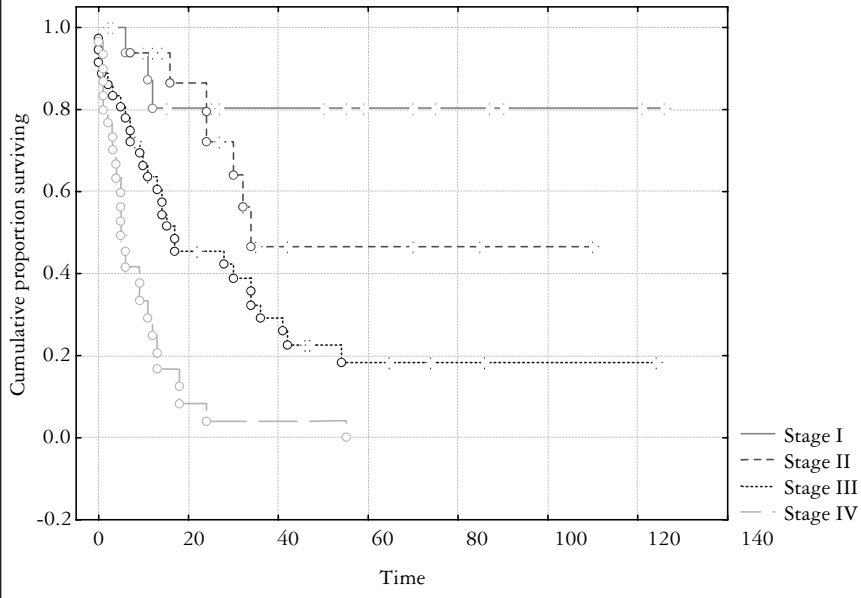

FIGURE 2. Survival curves for TNM stages of patients operated for gastric cancer

When gastric resection was possible on the first period, it was performed without on table assessment of the surgical specimen to confirm safety margins. In addition, oncologically adequate lymph node dissection has not been performed. On the second period, besides observing surgical safety margins, the involved lymph node basins, according to the Japanese Association for Gastric Cancer ${ }^{(27,28,40)}$ have been also removed.

As a result of increased demand, which resulted from the increased number of endoscopies, there was an increase in the number of patients with stage I lesions, assessed by the pathologic TNM staging (UICC $1987^{(23)}$ and $1997^{(51)}$ ) of the surgical specimen (pTNM), when compared to the first period $(P=0.0001)$ (Figure 3$)$.

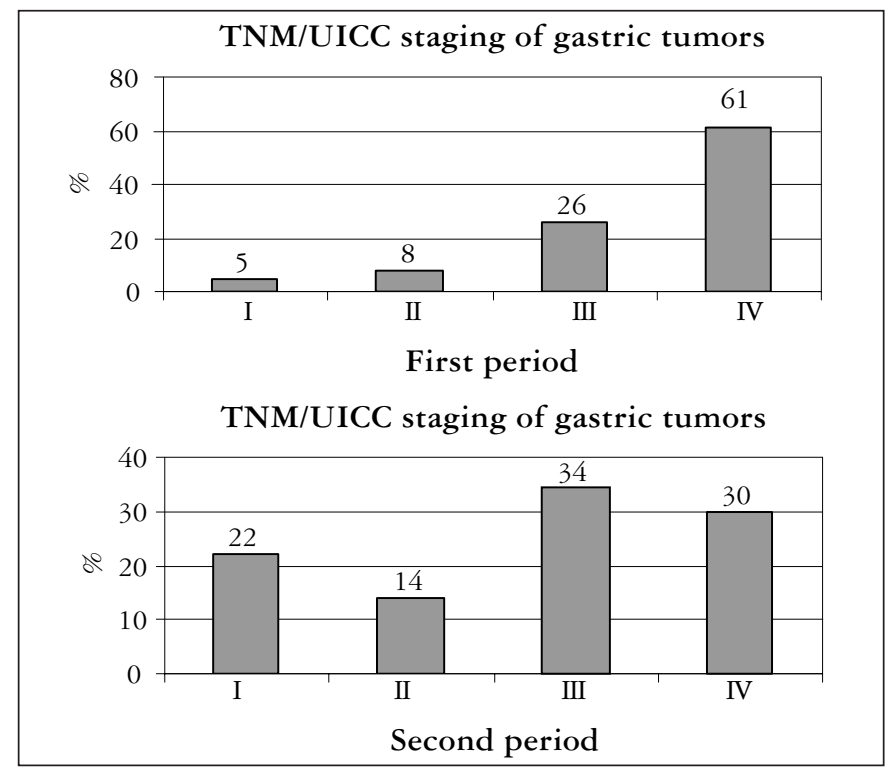

FIGURE 3. Comparison of TNM staging of patients operated for gastric cancer for both periods
By surgical procedures being performed exclusively by the SSISS and with the establishment of pre- and postoperative routines, in-hospital post-operative mortality rates decreased from $9 \%$ to $6 \%$ and have recently decreased to $3 \%$ in the past 3 years.

Patients were followed-up in the SSISS in the out-patient unit. An active search for patients who do not return on followup appointments is also performed. Survival curves according to Kaplan-Meier are performed yearly for all disease stages and are presented in Figure 2.

Since January 2004, the SWOG - 9008/INT0116 was adopted as adjuvant treatment for posterior analysis ${ }^{(34)}$.

\section{DISCUSSION}

The division of the Digestive Surgery into specific units for specialized treatment of diseases of the esophagus, stomach and small intestine, liver and billiary tract at the University Hospital of Santa Maria, as other similar University Hospitals in Brazil, including the University Hospitals attached to the Universities of São Paulo and Porto Alegre aimed to concentrate the experience of professionals in these fields and, with time, to increase expertise, skills and to establish appropriate actions to be used and discussed with other experts in the field. The aim of this analysis was to confirm whether the reduction in the area of expertise of these professionals is balanced by the expansion of knowledge of their specific field and whether this results in a real benefit for patients. It is well defined among many authors that the more surgical volume a surgeon has, the lower the rate of mortality and of complications ${ }^{3}$, 18, 44). Furthermore, specialized units also present this gap when compared to non-specialized units. McCULLOCH ${ }^{(36)}$ reported a mortality rate of $16 \%$ and a morbidity rate of $49 \%$ in gastric resections for cancer in a general hospital, emphasizing the need to concentrate experience in order to improve these results.

Looking for information from the patient point of view, we have participated for 10 years in a gastric cancer patient website (http://www.acor.org/stomach-onc.html), and have been able to observe a number of doubts about the disease and difficulties with treatment. Access to the internet is still restricted in Brazil, mainly among the poor population and, therefore, it is necessary to spread information through other ways. Both types of publicity brought together a group of patients who sought appointments at the SSISS. After complaints and rigorous physical examination, patients were selected for an upper gastrointestinal endoscopic examination based on the following criteria: patients of both sexes 45 years old or over with epigastric pain or dyspepsia, mainly when combined with appetite or weight loss, decreased hemoglobin, history of low intake of fruits and vegetables and a high intake of salty or smoked meat, or family history of first degree relatives with gastric cancer. CHRISTIE et al. ${ }^{(10)}$ stated that this approach can only be justified for patients with uncomplicated dyspepsia over 55 years old. Obviously, patients with signs suggestive of disseminated disease, such as ascites, Blummer's sign, palpable 
lymph nodes such as Virchow's or sister Mary Joseph's and nodular liver enlargement were also selected for an upper gastrointestinal endoscopy.

This assessment resulted in a great number of patients with an endoscopic diagnosis of normal findings or benign diseases. However, it also provides an increase from $5 \%$ to $22 \%$, of patients with stage I gastric cancer. Although stage I by no means signifies early cancer, based on the IB group from the 1997 UICC classification, it is certainly associated with a better prognosis. This same result has already been reported, both by the Japanese authors and SUE-LING et al. ${ }^{(52)}$ and, likewise, are based on a greater number of upper gastrointestinal endoscopies. Nevertheless, this results in a higher cost, only justifiable, according to CORREA et al. ${ }^{(11)}$, in regions with a high incidence of gastric cancer. PARKIN et al. ${ }^{(45)}$ estimated that to detect one case of gastric cancer, 2,877 male patients over the age of 45 would have to be examined in countries with a low incidence of gastric cancer, such as the United States, whereas it would only be necessary to examine 253 patients with the same characteristics in a country with high incidence, such as Japan. In the southern region of Brazil, there is an intermediate incidence there are no studies regarding the cost/benefit relation to these cases.

As for operability, we believe that all patients that could be submitted to potentially curative surgery, i.e., locally advanced disease suitable for complete resection (R0), should undergo laparotomy. Unfortunately, this occurs in $15 \%$ to $64 \%$ of cases submitted to surgery ${ }^{(15,36,47)}$. This means that pre-operative staging should be as rigorous as possible in order to thoroughly define patients with diffuse or unresectable disease. Our rate of operability is still high $(86 \%)$, similar to other important series published until the 90 's ${ }^{(2)}$, though it has decreased since the second half of the second period when laparoscopy assessment was added as part of the staging, thereby coming closer to more recent series $^{(39,53)}$. This is because laparoscopy can assess peritoneal implants that are difficult to detect in routine imaging exams and, in such cases, precludes palliative surgery ${ }^{(24,35)}$, leading to complementary procedures, such as neo-adjuvant chemotherapy $^{(9,32,33,43,46)}$.

There are many supporters of palliative resections, mainly in the case of tumor bleeding or gastric obstruction ${ }^{(25,42)}$, which are not indications for laparoscopy as a staging tool ${ }^{(35)}$.

It can be clearly observed a progress in our in-hospital mortality rate following gastric resection comparing the first with the second period, which is within the acceptable range, i.e., between $2 \%$ and $13 \%$, and almost reaching the lowest ones $^{(6,13,14,19,22,38,41,50,55)}$ As for surgical procedures, lack of observation of surgical margins is a deterrent factor that may significantly shorten patient perspective of survival ${ }^{(53)}$ and as much as possible a $6 \mathrm{~cm}$ margin of resection should be attempted.

The D2 lymphadenectomy was adopted as routine, according to "Associação Brasileira do Câncer Gástrico"(16) and Japanese Gastric Cancer Association ${ }^{(29,48)}$ recommendations. Although the extensive review recently performed by McCULLOCH et al. ${ }^{(37)}$ has concluded that D2 dissection is not beneficial there is a favorable trend in the T3+ group that similarly accounts for the majority of our patients. The two random, and already acclaimed studies, that warn on the increased morbidity and mortality rates of the procedure ${ }^{(4,5,12,13)}$, point out splenectomy and distal pancreatectomy as routine procedures, which seems to be unnecessary ${ }^{(37)}$, unless in the case of direct invasion of the tumor; combined splenectomy is performed among us only in the evidence of direct invasion or uncountable splenic art. lymph nodes are involved. Pancreatectomy is considered an exception and it is also only used in cases of direct invasion, since in most cases, it is possible to dissect group 11 lymph nodes without resection of the distal pancreas ${ }^{(48)}$.

As for combined treatment, mainly adjuvant, in the first period, it was believed that there was no benefit for patients, with a very low response rate and a high morbidity rate ${ }^{(43)}$. Later, with the development of new drugs and the published results by MacDONALD et al. ${ }^{(34)}$, the SWOG 9008/INT 0116 protocol was adopted to assess patients undergoing D2 gastrectomy. There are many studies and protocols testing new drugs, some of them using drugs given by mouth, which stimulates the use of neoadjuvant regimens and leads to downstaging in stage IV tumors allowing further curative surgery $(21,25,33,42)$.

All these strategies for treating gastric cancer patients are only possible if patients are adequately followed-up. For this reason, in the second period, the majority of our patients were followed-up and survival curves were annually assessed to observe outcome in detail.

In conclusion, we believe that the creation of specialized surgical units, such as the SSISS of the University Hospital of Santa Maria for the treatment of gastric cancer has brought unquestionable benefits when compared to the non specialized service running before, and is a policy that should be stimulated with the goal of attempting better quality in health care for the population.

\section{ACKNOWLEDGEMENT}

The authors are grateful to Dr. Luis Fernando Moreira for reviewing this paper. 
Souza FO, Pereira DV, Santos LH, Antunes L, Chiesa J. Estudo comparativo entre cirurgia geral e cirurgia especializada no tratamento de pacientes com câncer gástrico. Arq Gastroenterol. 2008;45(1):28-33.

RESUMO - Racional - Embora a incidência de câncer gástrico esteja diminuindo em muitos países, ainda é a segunda causa de morte por câncer mundialmente. O prognóstico desta doença é reservado e depende, entre outros fatores, do diagnóstico precoce e da experiência da equipe cirúrgica. Objetivo - Comparar os resultados obtidos no tratamento de pacientes com câncer gástrico em um hospital universitário, inicialmente por uma equipe de cirurgia geral e posteriormente por outra especializada no tratamento dessa doença. Métodos - Os pacientes foram cronologicamente divididos em dois grupos: o primeiro tratado pela cirurgia geral (grupo 1, $\mathrm{n}=136,1984-1993$ ) e o segundo pela equipe de cirurgia gástrica (grupo 2, $\mathrm{n}=149,1994-2003$ ). As características clínicas e patológicas e as taxas de sobrevida foram avaliadas. Resultados - Durante um período de 20 anos de tratamento, menor número de pacientes foi submetido a cirurgia no segundo período ( $94 \%$ vs $86 \%$ ), foram realizadas mais endoscopias digestivas altas no segundo período, resultando em maior número de tumores em estágio I ( $5 \%$ vs $22 \%$ ). Também as gastrectomias D2 foram mais realizadas e as margens de segurança cirúrgicas respeitadas. A mortalidade cirúrgica diminuiu de $9 \%$ para $6 \%$, e tratamentos complementares como radio e quimioterapia adjuvantes foram realizados no segundo período. Conclusão - Equipes cirúrgicas especializadas são necessárias para a obtenção de melhores resultados no tratamento de pacientes com câncer gástrico.

DESCRITORES - Neoplasias gástricas, cirurgia. Gastrectomia.

\section{REFERENCES}

1. Ajani JA. Operate on my stomach cancer? Oh, no - not you, or not yet. J Clin Oncol 2004;22:1763-4.

2. Akoh JA, MacIntyre IM. Improving survival in gastric cancer: review of 5-year survival rates in English language publications from 1970. Br J Surg. 1992;79:293-9.

3. Birkmeyer JD, Stukel TA, Siewers AE, Goodney PP, Wennberg DE, Lucas FL. Surgeon volume and operative mortality in the United States. N Engl J Med. 2003;349:2117-27.

4. Bonenkampf JJ, Songun I, Hermans J, Sasako M, Welvaart K, Plukkler JT, van Elk P, Obertop H, Gouma DJ, Taat CW. Randomized comparison of morbidity after D1 and D2 dissection for gastric cancer in 996 Dutch patients. Lancet. 1995;345:745-8.

5. Bonenkampf JJ, Hermans J, Sasako M, van de Velde CJ. Extended lymph node dissection for gastric cancer. N Engl J Med. 1999;340:908-58.

6. Borch K, Jönsson B, Tarpila E, Franzén T, Berglund J, Kullman E, Franzén L. Changing pattern of histologic type, location, stage and outcome of surgical treatment of gastric carcinoma. Br J Surg. 2000;87:1474-8.

7. Brasil. Ministério da Saúde. INCA - Instituto Nacional do Câncer. [online] Estimativa de incidência e mortalidade por câncer no Brasil. 2005. Disponível em: http://www.inca.gov.br/

8. Brennan MF. Current status of surgery for gastric cancer: a review. Gastric Cancer. 2005;8:64-70.

9. Burke EC, Karpeh MS, Conlon KC, Brennan MF. Laparoscopy in the management of gastric carcinoma. Ann Surgery. 1997;225:262-7.

10. Christie J, Shepherd NA, Codling BW, Valori RM. Gastric cancer below the age of 55: implications for screening patients with uncomplicated dyspepsia. Gut. 1997;41:513-7.

11. Correa P, Piazuelo MB, Camargo MC. The future of gastric cancer prevention. Gastric Cancer. 2004; 7:9-16.

12. Cuschieri A, Joypaul V, Fayers P, Cook P, Fielding J, Craven J, Bancewicz J, Joypaul V, Cook P. Postoperative morbidity and mortality after D1 and D2 resections for gastric cancer: preliminary reports of the MRC randomized controlled surgical trial. The surgical cooperative group. Lancet. 1996;347:995-9.

13. Cuschieri A, Weeden S, Fielding J, Banciewicz J, Craven J, Joypaul V, Sydes M, Fayers P. Patient survival after D1 and D2 resections for gastric cancer surgery: long term results of the MRC randomized surgical trial. Br J Cancer. 1999;79:1522-30.

14. de Manzoni G, Verlato G, Guglielmi A, Laterza E, Genna M, Cordiano C. Prognostic significance of lymph node dissection in gastric cancer. Br J Surg. 1996;83:1604-7.

15. Degiuli M, Sasako M, Ponti A, Soldati T, Danese F, Calvo F. Morbidity and mortality after D2 gastrectomy for gastric cancer: results of the Italian Gastric Cancer Study Group prospective multicentre surgical study. J Clin Oncol. 1998;16:1490-3.

16. Del Grande JC, Martinez JC, Gama-Rodrigues JJ, Rocha RA. Linfadenectomia. In: Gama-Rodrigues J, Del Grande JC, Martinez JC, editores. Tratado de clínica cirúrgica do sistema digestório. São Paulo: Atheneu; 2004. p. 615-23.

17. Desai AM, Pareek M, Nightingale PG, Fielding JW. Improving outcomes in gastric cancer over 20 years. Gastric Cancer. 2004;7:196-203.

18. Finlayson EV, Goodney PP, Birkmeyer JD. Hospital volume and operative mortality i cancer surgery. Arch Surg. 2003;138:721-5.

19. Gama-Rodrigues JJ, Bresciani CJ, Matsuda M. Câncer gástrico. In: Pinotti HW, editor. Tratado de clínica cirúrgica do aparelho digestivo. São Paulo: Atheneu; 1994. p.624-34.
20. Gama-Rodrigues J, Bresciani C, Jacob CE, Santos VR, Habr-Gama A, Matsuda M, et al. Treatment of early gastric cancer: results of D2 lymphadenectomy. In: 4th International Gastric Cancer Congress: New York, USA, April 30-May 2, 2001; editors, Murray F. Brennan, Martin S. Karpeh. Bologna: Monduzzi; c2001. p.213-32.

21. Hamada M, Tsuji A, Iwata J, Nishioka Y, Ozaki K, Shima Y, Horimi T. Neoadjuvant chemotherapy with S-1 and surgical resection for a mucinous gastric cancer with peritonial dissemination. Gastric Cancer. 2005;8:50-4.

22. Hara H, Isozaki H, Nomura E, Fujii K, Sako S, Tanigawa N. Evaluation of treatment strategies for gastric cancer in the elderly, according to the number of abnormal parameters on preoperative examination. Surg Today. 1999;29:837-41.

23. Hermanek P, Sobin LH. UICC TNM classification of malignant tumors. 4th ed. Berlin: Springer; 1987.

24. Hokita S, Ishigami S, Sumikura S, Hogashi H, Sakita H, Nakajo A et al. The significance of the non-curative resection for advanced gastric cancer. In: 4th International Gastric Cancer Congress: New York, USA, April 30-May 2, 2001; editors, Murray F. Brennan, Martin S. Karpeh. Bologna: Monduzzi; c2001. p.310.

25. Hong YS, Song SY, Lee SI, Chung HC, Choi SH, Noh SH, Park JN, Han JY, Kang JH, Lee KS, Cho JY. A phase II trial of capecitabine in previously untreated patients with advanced and/or metastatic gastric cancer. Ann Oncol. 2004; $15: 1344-7$.

26. Jacob CE, Gama-Rodrigues J, Bresciani CJ, Iryia K, Sakano AI, Habr-Gama A. Shifting proportion of gastric adenocarcinoma from 1971 to 1998. In: In: 4th International Gastric Cancer Congress: New York, USA, April 30-May 2, 2001; editors, Murray F. Brennan, Martin S. Karpeh. Bologna: Monduzzi; c2001. p.154-71

27. Japanese Gastric Cancer Association. Japanese classification of gastric carcinoma - 2nd ed. Gastric Cancer. 1998;1:10-24.

28. Japanese Research Society for Gastric Cancer. Japanese classification of gastric carcinoma. Japanese Research Society for Gastric Cancer. Tokyo: Kanehara; 1995. p. 104 .

29. Kajitani T. Japanese Research Society for the Study of Gastric Cancer: the general rules for gastric cancer study in surgery and pathology. Jpn J Surg. 1981;11:127-47.

30. Kaplan EL, Meier P. Nonparametric estimate for incomplete observations. J Am Stat Assoc. 1958;53:457-81.

31. Kato Y, Nakamura S, Arai K, Konishi T, Takeshita K, Sano T, Hattori T, Sasako M. Meeting report: The $75^{\text {th }}$ Congress of the Japanese Gastric Cancer Association. Gastric Cancer. 2004;7:3-8.

32. Lony AM, Mansfield PF, Leach SD, Ajani J. Laparoscopic staging for gastric cancer Surgery. 1996;119:611-4.

33. Lordick F, Siewert JR. Recent advances in the multimodal treatment for gastric cancer: a review. Gastric Cancer. 2005;8:78-85.

34. MacDonald JS, Smalley SR, Benedetti J, Hundahl S, Estes NC, Stemmermann GN Haller DG, Ajani JA, Gunderson LL, Jessup JM, Martenson JA. Chemoradiotherapy after surgery compared with surgery alone for adenocarcinoma of the stomach or gastroesophageal junction. N Engl J Med. 2001;3215:725-30.

35. Martinez JC, Del Grande JC, Herbella FA. Ressecção paliativa no câncer gástrico. In: Gama-Rodrigues J, Del Grande JC, Martinez JC, editores. Tratado de clínica cirúrgica do sistema digestório. São Paulo: Atheneu; 2004. p.582-9.

36. McCulloch P. Should general surgeons treat gastric carcinoma? An audit of practice and results, 1980-1985. Br J Surg. 1994;81:417-20.

37. McCulloch P, Niita ME, Kazi H, Gama-Rodrigues JJ. Gastrectomy with extended lymphadenectomy for primary treatment of gastric cancer. Br J Surg. 2005;92:5-13. 
38. Moriwaki Y, Kobayashi S, Kunisaki C, Harada H, Imai S, Kasaoka C. Is D2 lymphadenectomy in gastrectomy safe with regard to the skill of the operator? Dig Surg. 2001;18:111-7.

39. Mullaney PJ, Wadley MS, Hyde C, Wyatt J, Lawrence G, Hallissey MT, Fielding JW Appraisal of compliance with the UICC/AJCC staging system in the staging of gastric cancer. Br J Surg. 2002;89:1405-8

40. Nakajima T. Gastric cancer treatment guidelines in Japan. Gastric Cancer. 2002;5:15 .

41. Noguchi M, Miyazaki I. Prognostic significance and surgical management of lymph node metastasis in gastric cancer. Br J Surg. 1996;83:156-61.

42. Ohtsu A. Current status and future prospects of chemotherapy for metastatic gastric cancer: a review. Gastric Cancer. 2005;8:95-102.

43. Oliveira DR, Ribeiro Jr U, Bitelman B, Polak M, Bresciani C, Gama-Rodrigues J, Laudana AA, Pinotti HW. O método laparoscópico na avaliação pré-operatória de pacientes com neoplasia maligna de estômago. Rev Hosp Clin Fac Med São Paulo. 1993;48:4-7.

44. Parikh D, Johnson M, Chagla L, Lowe D, McCulloch P. D sub 2 gastrectomy: lessons from a prospective audit of the learning curve. Br J Surg. 1996;83:1595-9.

45. Parkin DM, Whelan SL, Ferlay J, Raymond L, Young J. Cancer incidence in five continents, v.7(143). Lyon: IARC (International Agency for Research on Cancer); 1997.

46. Possik RA, Franco EL, Pires DR, Wohnrath DR, Ferreira EB. Sensivity, specificity and predictive value of laparoscopy for the staging of gastric cancer and the detection of liver metastasis. Cancer. 1986;58:1-6.

47. Saka M, Mudan SS, Katai H, Sano T, Sasako M, Maruyama K. Pancreaticoduodenectomy for advanced gastric cancer. Gastric Cancer. 2005;8:1-5.
48. Sano T, Sasako M, Yamamoto S, Nashimoto A, Kurita A, Hiratsuka M, Tsujinaka T, Kinoshita T, Arai K, Yamamura Y, Okajima K. Gastric cancer surgery: morbidity and mortality results from a prospective randomized controlled trial comparing D2 and extended para-aortic lymphadenectomy - Japan Clinical Oncology Group Study 9501. J Clin Oncol. 2004;22:2767-73.

49. Sano T. An international forum for discussion of gastric cancer is needed, particularly now. Gastric Cancer. 2005;8:133-4.

50. Siewert JR, Kestlmeier R, Busch R, Böttcher K, Roder JD, Müller J, Fellbaum C, Hofler $\mathrm{H}$. Benefits of D2 lymph node dissection for patients with gastric cancer and pN0 and pN1 lymph node metastasis. Br J Surg. 1996;83:1144-7.

51. Sobin LH, Wittekind Ch, editors. TNM: classification of malignant tumors. 5th ed New York: Wiley-Liss; 1997.

52. Sue-Ling HM, Johnston D, Martin IG, Dixon MF, Lansdown MR, McMahon MJ, Axon AT. Gastric cancer: a curable disease in Britain. Br Med J. 1993;307:591-5.

53. Wanebo HJ, Kennedy BJ, Chmiel J, Steele G, Winchester D, Osteen R. Cancer of the stomach. A patient care study by the American College of Surgeons. Ann Surg. 1993;218:583-92.

54. WHO (World Health Organization). The world health report. Geneva: WHO, 2004

55. Yildirim E, Celen O, Berberoglu U. The Turkish experience with curative gastrectomies for gastric carcinoma: is D2 dissection worthwhile? J Am Coll Surg. 2001;192:25-37. 